\title{
RESULTS OF CONJUNCTIVAL AUTOGRAFT IN PTERYGIUM SURGERY IN LUMBINI EYE INSTITUTE, NEPAL
}

Dhakhwa $\mathrm{K}^{1}$,Patel $\mathrm{S}^{2}$, Sharma $\mathrm{MK}^{3}$, Rai SKC $\mathrm{C}^{1}$ Bhari $\mathrm{AM}^{2}$

\section{ABSTRACT}

BACKGROUND: A pterygium is a wedge shaped fibrovascular growth of conjunctiva that extends onto the cornea. Various surgical techniques are used to treat this condition. Conjunctival graft over the bare sclera is one of the techniques used. The present study was done to evaluate the efficacy of autologous conjunctival graft in surgical management of primary and recurrent pterygium.

MATERIALS AND METHODS: All the patients who underwent conjunctival autograft surgery for primary and recurrent pterygium from $1^{\text {st }} \mathrm{Jan}$. 2010 to $30^{\text {th }}$ June 2010 were enrolled prospectively. Follow up was done for six months after the surgery.

RESULTS: A total of 240 patients operated for primary and recurrent pterygium were enrolled in this study. There were $107(44.6 \%)$ male and $133(55.4 \%)$ female with male to female ratio 1: 1.3. Patients' age ranged from 15 to 80 years. Recurrences occurred in $3(1.25 \%)$ cases.

CONCLUSIONS: Free conjunctival autograft is a safe and effective procedure for prevention of recurrence in pterygium surgery.

KEYWORDS: Pterygium, Conjunctival autograft, Recurrence

1. Associate Professor, Lumbini Eye Institute, Bhairahawa, Nepal

2. Ophthalmologist, Lumbini Eye Institute, Bhairahawa, Nepal

3. Additional Professor, Department of Ophthalmology, B.P. Koirala Institute of Health Sciences, Dharan, Nepal

\section{For correspondence}

Dr. Kavita Dhakhwa, MD

Associate Professor,

Lumbini Eye Institute,

Bhairahawa, Nepal

Email:drkavitadh@gmail.com 


\section{INTRODUCTION}

Since the days of Sushruta, pterygium has been well recognized. It is a disturbing condition both for the patient because of their unsightly appearance and for the surgeon because of their tendency to recur. ${ }^{1}$ Pterygium is a wedge shaped fibrovascular growth of conjunctiva that extends onto the superficial cornea. Pterygium is a benign lesion that can be found on either side of cornea but frequently in nasal side than temporal. ${ }^{2}$ Sometimes, it is also seen superio-nasally or infro-nasally or even rarely superio-temporally or infrotemporally.

The exact cause of pterygium is unknown but is associated with excessive exposure to sun, wind and dust. So the population who work outdoors are exposed to sun and wind are more prone to develop pterygium. It is more common in tropical and subtropical region. ${ }^{3}$

Various surgical techniques are used to treat pterygium which includes bare sclera technique with or without adjunctive therapy like Mitomycin $\mathrm{C}^{4}, 5$ Fluorouracil ${ }^{5}$, Beta-radiation ${ }^{6}$, Thiotepa eye drops, Cyclosporine drop instillation. ${ }^{7}$ Other than these techniques amniotic membrane transplantation over the bare sclera has been described. ${ }^{8}$ Still the successful management of pterygium is a constant challenge for ophthalmologist due to high recurrence rate varying from $2.1 \%$ to $87 \% .9$ The recurrence is defined as growth of fibrovascular tissue of more than $1 \mathrm{~mm}$ over the cornea of previous pterygium excision. ${ }^{10}$ So the newer techniques are evolving from time to time. One of the alternative techniques is conjunctival autograft transplant over the bare sclera which was popularized by Kenyon et $\mathrm{al}^{11}$ minimizing the recurrence rate. Recently Koranyi et al published a cut and paste technique in primary pterygium with fibrin glue, in which recurrence rate was minimal. ${ }^{12}$ This technique is now getting popularity among corneal surgeons because of lesser irritation and complication in post-operative period and with very low recurrence rate. The latest technique is claimed to be the sutureless, glueless cut and paste technique. In this context the present study was done to evaluate the efficacy and outcome of conjunctival autograft transplant in the treatment of pterygium.

\section{MATERIALSAND METHODS}

It was a prospective study conducted in Lumbini Eye Institute (LEI), Nepal from $1^{\text {st }}$ January 2010 to $31^{\text {st }}$ Dcember 2010. Institutional ethical clearance was taken. All the patients with primary and recurrent pterygium who presented to the cornea clinic of Lumbini Eye Institute and underwent pterygium surgery from $1^{\text {st }}$ January to $30^{\text {th }}$ June 2010 were included in the study. Written informed consent was taken. All patients who gave the consent were examined in outpatient clinic of cornea department. All the data was entered in a predesigned proforma. Detailed history about the chief complaints, duration of growth, occupation, previous surgical or medical treatment were inquired and recorded. In the history, it was also noted whether the pterygium was primary or recurrent, and in case of recurrent pterygium, number of previous surgeries was also noted. Preoperatively, all patients were administered antibiotic and steroid drops (Prednisolone acetate $1 \%$ eye drop) 4 times a day for one day prior to surgery.

\section{SURGICALTECHNIQUE}

The surgical technique involved transplanting conjunctival graft from the superior bulbar conjunctiva over the exposed bare sclera of the same eye after pterygium (primary and recurrent) excision. Suture was applied with 10-0 Nylon.

Peribulbar anesthesia was administered which consisted 50:50 mixture of $5 \mathrm{ml}$ of $2 \%$ Lidocaine and $0.5 \%$ Bupivacaine with $150 \mathrm{units} / \mathrm{ml}$ of Hyaluronidase. After inserting a lid speculum, the pterygium body including the adjacent Tenon's capsule was cut, avoiding the damage to the medial rectus muscle. The pterygium head was peeled off from the cornea.

On the donor side, the graft had to be as wide as the area where the pterygium was removed. The bulbar conjunctiva was dissected leaving the underlying Tenon's capsule intact. The conjunctiva was excised with Vannas scissor and the graft was rotated to the area where pterygium had been removed, placing the limbal side of the donor graft to the limbal side of the recipient bed. The limbal portion of the graft was first secured with 10-0 Nylon with two interrupted conjunctival sutures superiorly and inferiorly anchoring the limbus. The conjunctival portion was then anchored to the adjacent conjunctiva using 10-0 Nylon sutures. All patients were patched overnight and examined first post-operative day. Topical antibiotics (Gtt.Ofloxacin $0.3 \%$ ) and steroid drops (Gtt. Prednisolone acetate 1\%) were used 4 times a day for 15 days and then tapered off within 1 month. Oral NSAIDs were administered for 3 days.

Patients were reviewed after 15 days, 45 days and then after 3 months and 6 months. During follow up, operated eye was examined under slit lamp and post-operative complications and recurrence were recorded. The recurrence of pterygium was confirmed if the regrowth of fibrovasular tissue is more 
than $1 \mathrm{~mm}$ crossing the corneo-scleral limbus into the area of previous excision.

\section{RESULTS}

A total number of 240 patients, 231 with primary and 9 with recurrent pterygium were included in the study. Among them, $107(44.6 \%)$ were male and $133(55.4 \%)$ females. Male: Female ratio was $1: 1.3$. Pterygiums are more common in farmers than in city dwellers. In our study, among 240 patients, 144 were involved in field work.

Picture 1: Pterygium preoperatively

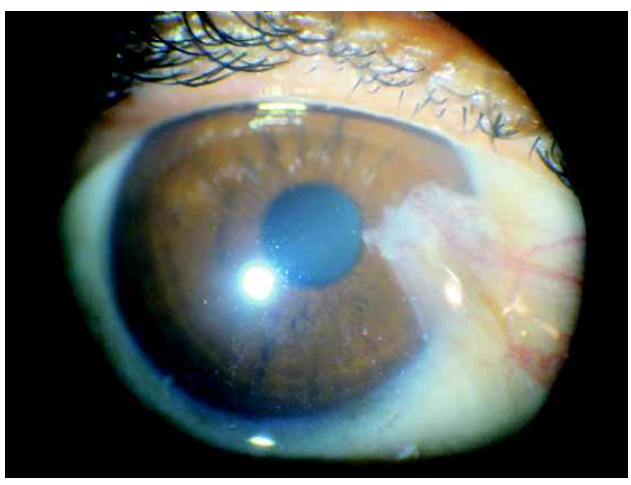

Picture 2: First postoperative day after pterygium excision with autologous graft

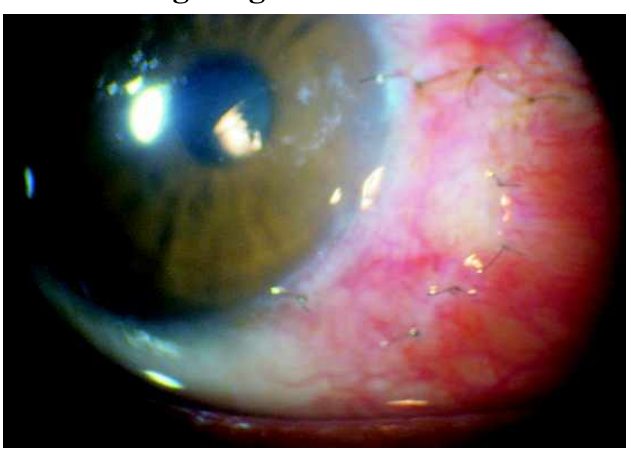

Picture 3: One month after pterygium surgery with autologous graft

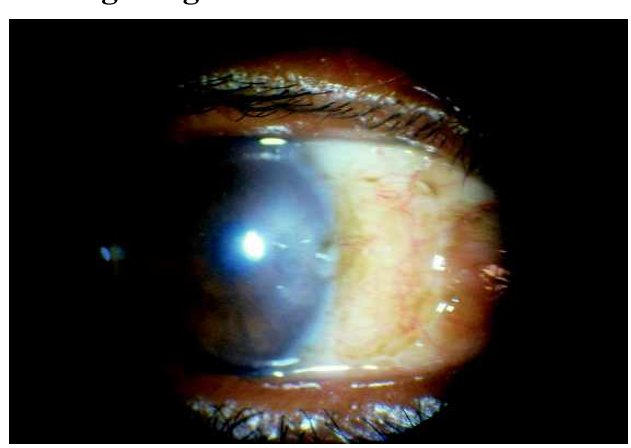

Prevalence and incidence rates differ with respect to age. Although the elderly have the highest rate of prevalence, a much younger group of 20-40 years age group has highest incidence rate which is similar to our study, 80 patients were in this group in present study. The distribution of cases was almost similar from 31-60 years.

Figure 1: Age group of 240 patients with pterygium

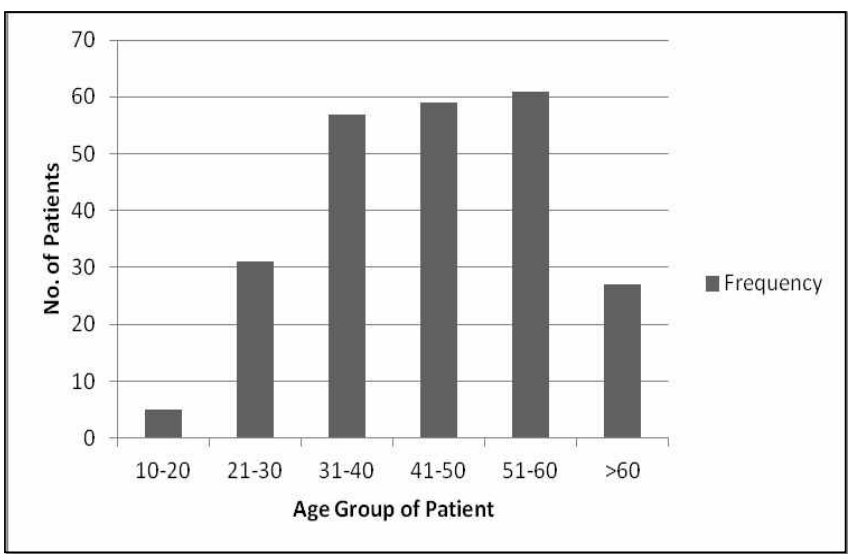

113 patients presented with pterygium after it was noticed for 2 years or more. There were 12 patients who had double pterygium. The cause of the late presentation may be due to their low socio-economic condition and unawareness of the problem and it's consequences. (Table.1)

Table 1: Duration of illness

\begin{tabular}{|l|l|}
\hline Duration of illness & Numberof patients(\%) \\
\hline$<6$ months & $5(2.1)$ \\
\hline $6-11$ months & $30(12.5)$ \\
\hline $1-2$ years & $92(38.3)$ \\
\hline$>2$ years & $113(47.1)$ \\
\hline Total & $240(100)$ \\
\hline
\end{tabular}

All 240 patients were followed up for 6 months, where recurrences occurred in $3(1.25 \%)$ cases. In 45 days follow up period, all (100\%) patients were present. At 3 months 15 $(6.5 \%)$ patients and at 6 months $30(12.5 \%)$, patients were lost to follow up.

There was no major complication such as perforation, scleral melt or endophthalmitis. Minor post-operative complications were conjunctival cyst formation in $2(0.83 \%)$ cases, dellen 1 $(0.42 \%)$ case, episcleritis $1(0.42 \%)$ case, odematous graft in 1 $(0.42 \%)$ case, viral keratitis in $2(0.83 \%)$ cases, and flap 
necrosis in $3(1.25 \%)$ cases. A sign of recurrence that is regrowth of fibrovascular tissue $1 \mathrm{~mm}$ or more crossing the corneoscleral limbus to the area of previous excision was noticed in those 3 cases with flap necrosis till 6 months of duration.

Table 2: Complications

\begin{tabular}{|l|l|}
\hline Types of complications & No. of patients (\%) \\
\hline Conjunctival cyst & $2(0.83)$ \\
\hline Dellen & $1(0.42)$ \\
\hline Episcleritis & $1(0.42)$ \\
\hline Graft oedema & $1(0.42)$ \\
\hline Flap necrosis & $3(1.25)$ \\
\hline Viral keratitis & $2(0.83)$ \\
\hline Elevated IOP due to topical steroid & $14(15.7)$ \\
\hline
\end{tabular}

One of the frequent post-operative complications included increase in intraocular pressure (IOP), due to use of topical steroid which was noted in $14(15.7 \%)$ patients.

\section{DISCUSSION}

Pterygium excision is considered as minor procedure and little attention is paid to the problem of recurrence. But the unpredictable rate and timing of recurrence is of concern both to the patient and the surgeon.

In this study, conjunctival autograft transplantation successfully treated 240 eyes with pterygium. The recurrence rate was very low $1.25 \%$, which may indicate the technique compares favourable with the other methods. Several techniques for excision of pterygium are reported ${ }^{13,14}$ some of them reported very low recurrence rate. According to the results of several studies, recurrence rate of pterygium surgery with conjunctival autografting is as low as $1-2 \%$ compared to $24-89 \%$ in bare sclera technique and recurrence somewhere between $2.6 \%$ and $10.7 \%$ for primary pterygia and as high as $37.5 \%$ for recurrent pterygia with amniotic membrane grafting, ${ }^{15}$ make this technique superior to others. In another comparative study by Nazullah et al, the recurrence rate was $36.6 \%$ in bare sclera technique while in conjunctival autograft technique, it was $6.6 \% .^{16}$ This study also showed the conjunctival autograft technique is one of the best techniques for the pterygium surgery.
Adjuvant therapies like Mitomycin C, 5 Fluorouracil, Thiotepa and Beta irradiation have been proposed along with or without conjunctival graft to reduce the recurrence but are associated with complications like delayed epithelial healing, sclera melting, infections, glaucoma and endophthalmitis. Ashok $\mathrm{K}$ et al reported the recurrence rate as low as $2.6 \%$ which is quite similar to ours. But in their surgery, they have included the superior corneal and limbal tissue along with conjunctival graft which was transplanted to the bare sclera. ${ }^{17}$ In another study conducted in Nepal by Sharma $R$ et al the recurrence rate was $8.85 \%$ which is quite higher in comparison to our study although they have included the limbal tissue along with the conjunctival autograft. ${ }^{18}$ In other study by Rashid $\mathrm{H}$ et al who described a recurrence rate of $9.52 \%$ for both primary and recurrent pterygium, ${ }^{19}$ is quite higher in comparison to our study.

Recurrence of pterygium is very annoying complication both to the patients and the surgeon. So the proper and meticulous surgical procedure is the only way to avoid this complication. The result of the technique used in this study encourages surgeons to use this technique more often in the future.

Systemic administration of corticosteroids is least likely to induce glaucoma. However elevation of Intraocular pressure may occur as long as weeks to years after treatment. ${ }^{20}$ Glucocorticoid therapy can cause elevated intraocular pressure (IOP) in many susceptible individuals who are often referred to as "steroid responders". Approximately $40 \%$ of the general population can develop IOP elevation $(>5 \mathrm{mmHg}$ ) after topical ocular administration of a potent glucocorticoid for 3-6 weeks. ${ }^{21,22,23}$ A smaller percentage of these individuals (4-6\%) experience a large increase in IOP $(>15 \mathrm{mmHg}){ }^{24}$ Usually the IOP drops after a period of time that is said to be similar in length to the time spent on the steroid. However, developing glaucoma while on steroid is a genetic marker for being prone to develop glaucoma even without steroids. But in this study, all 14 patients showed the rise in IOP within 2 weeks of period which is slightly earlier than the usual period of elevation of IOP. The IOP was controlled in all cases with antiglaucoma medication within two weeks, while no one developed irreversible increase of IOP.

\section{CONCLUSION}

Conjunctival autograft transplant is an effective and safe procedure for the excision of primary as well as recurrent pterygia to prevent its recurrence. 


\section{REFERENCES}

1. Rosenthal JW. Chronology of pterygium therapy, Am JOphthal. 1953, 36: 1601. PMid:13104571

2. Micheal R, Edward GJ, Holland EJ. Management of pterygium. In: Krachmer JH, Mannis MJ, Holland EJ. Cornea Vol. 3 , surgery of cornea and conjunctiva, New York, Mosby 1997, 1873-85.

3. Saleem M, Muhammad L, Islam Z. Pterygium and dry eye, a clinical study. JPostgrad Med Inst. 2004; 18:558-62

4. Dar AJ, Chaudhary NH, Masud H, Khan MW.Role of Mitomycin $C$ in prevention of pterygium recurrence. Pak $J$ Ophthalmol 2001; 17: 8-14

5. Abraham LM, Selva D, Casson R, Leibovitch I. The clinical application of fluorouracil in ophthalmic practice. Drugs 2007; 67:237-55 http://dx.doi.org/10.2165/00003495200767020-00005 PMid:17284086

6. De Keizer RJ. Pterygium excision with free conjunctivalautograft versus postoperative Strontium Beta Irradiation.JFrOphthalmol 2001; 86: 111-15.

7. Hercules LA, Viveiros MM, Schellini SA, Candeias J, Padovani CR. Exposure of tenon capsule fibroblast of pterygium to cyclosporine 0.05\%, Arq Bas Oftalmol 2005; 69: 831-35. http://dx.doi.org/10.1590/S0004-27492006000600010

8. Prabhasawat $P$, Barton $K$, Burkett $G$ et al. Comparsion of conjunctivalautograft, Amniotic membrane grafts and primary closure of pterygium excision. Ophthalmology 1997; 104: 97485. http://dx.doi.org/10.1016/S0161-6420(97)30197-3

9. Gupta VP. Conjunctival transplantation for pterygium.DJO 1997; 5: 5-12.

10. Oguz H, Killitcioglu A, Yasar M. Limbal conjunctival miniautograft for preventing recurrence after pterygium surgery. EurJOphthalmol 2006; 16: 209-13.PMid:16703536

11. Kenyon $K R$, Wagoner $M D$, Hettinger ME. Conjunctival autograft transplantation for advanced and recurrent pterygium.Ophthalmology 1985; 92: 1461-70. http://dx.doi.org/10.1016/S0161-6420(85)33831-9

12. Koranyi G, Seregard S, Kopp ED. The cut and paste method for primary pterygium surgery: Long term follow up. ActaOphthalmolScand 2005; 83: 298-301. http://dx.doi.org/10.1111/j.1600-0420.2005.00465.x PMid:15948780

13. Allan BDS, Short P, Crawford GJ, Barett GD, Constable IJ. Pterygium excision with conjunctivalautografting: an effective and safe technique. BJO 1993; 77: 698-701.

http://dx.doi.org/10.1136/bjo.77.11.698
14. Massaontis $P$ et al. Clinical outcome study of a modified surgical technique for pterygium excision. Can $J$ Ophthal 2006; 41: 704-8. http://dx.doi.org/10.3129/i06-063 PMid:17224951

15. Krachmer, J. H. et al. Cornea, 2nd ed., Philadelphia: Elsevier Mosby, 2005, 1481.

16. Nazullah, Shah A, Ahmed M, Baseer A, Marwat SK, Saeed N. Recurrence rate of pterygium: A comparision of bare sclera technique and free conjunctivalautograft. J Med Sci. (Peshawar Print) 2010: 18(1): 36-39.

17. Sharma AK, Wali $V$, Pandita A. Corneo-conjunctival autografting in pterygium surgery. JK Science 2004; 6(3): 149152.

18. Sharma $R$, Marasini $S$, Nepal BP.Outcome of conjunctival autograft transplantation in pterygium surgery in a community based hospital in Nepal. Nepal J Ophthalmol 2012; 4(8):242247 PMid:22864029

19. Rashid HR, Rahman F, Khan SB, Hussain M. Results of conjunctival auto-transplant in pterygium surgery. Gomal $J$ of Medical Sciences 2010; 8(1): 82-84.

20. Bernstein HN, Schwartz B. Effects of long term systemic steroids on ocular pressure and tonographic values. Arch Ophthalmol 1962, 68: 742. http://dx.doi.org/10.1001/archopht. 1962.00960030746009 PMid:13967694

21. Armaly MF. Effect of corticosteroid on intraocular pressure and fluid dynamics $I$. The effect of dexamethasone in the normal eye. Arch. Ophthalmol 1963, 70:88. http://dx.doi.org/10.1001/archopht.1963.00960050484010 http://dx.doi.org/10.1001/archopht.1963.00960050494011

22. Armaly $M F$. Effect of corticosteroid on intraocular pressure and fluid dynamics II. The effect of dexamethasone in the glaucomatous eye. Arch. Ophthalmol 1963, 70: 492. http://dx.doi.org/10.1001/archopht.1963.00960050484010 http://dx.doi.org/10.1001/archopht.1963.00960050494011 PMid:14078871

23. Armaly MF. Inheritence of Dexamethasone hypertension and glaucoma. Arch. Ophthalmol.1967, 77:474. http://dx.doi.org/10.1001/archopht.1967.00980020749006

24. Clark $A F$, Wordinger RJ. Steroid glaucoma.Glaucoma world newsletters, no. 23; May 2001 